UDK 314.8(497)

\title{
ДЕМОГРАФСКЕ ПРОМЕНЕ У НЕКИМ БАЛКАНСКИМ ЗЕМЉАМА У ТРАНЗИЦИОНОМ КОНТЕКСТУ
}

\section{Резиме}

Демографске промене саставни су део дубљих друштвеноекономских промена кроз које су пролазиле балканске земље у другој половини 20. и почетком 21. века. Бројни неповољни демографски трендови су настављени или интензивирани, а неки демографски процеси (опадање природног прираштаја, старење становништва, депопулација) добили су израженије облике на подручју Балкана, тако да се њихово још снажније манифестовање очекује током 21. века. Промене демографске слике балканских земаља и разлике у репродукцији становништва условљене су сплетом околности социоекономске природе, многострукошћу деловања фактора етничке припадности, као и цивилизацијским и културолошким особеностима појединих друштвених група. У раду су из социодемографске перспективе сагледане промене у сфери природног кретања и старосној структури становништва неких балканских земаља током последњих неколико деценија. Проучавање особености појединих демографских структура, кретања становништва, брачног и репродуктивног понашања становништва индиректно упућује на одговор на питање о демографској будућности ових земаља.

Кључне речи: демографске промене, балканске земље, природно кретање становништва, депопулација, старење становништва.

\section{УВОД}

Друштвено-економске и политичке промене, трансформација друштвених система у послењој деценији 20. века и током 21. века, доприносе мењању демографске слике балканских земаља, тако да неповољни демографски трендови постају све наглашенији, али и препознатљиви као кључни социодемографски проблеми. Највећи број земаља на Балкану налази се у мултидимензионалном процесу транзиције, који дубоко захвата економски, политички и културни подсистем глобалног друштва, док „у оквирима свакодневице он продире у животне услове група и појединаца, редефинише њихове односе, мења понашања, очекивања, перспективе“ (Lazić, 2000: 21). У балканским земљама дешавале су се значајне политичке, економске и демографске промене, а бројне противуречности довеле до слома друштвених система и моралне аномије. „Балканска друштва, за разлику од друштава развијеног светског центра, живе у различитом

1 suzana.markovic.krstic@filfak.ni.ac.rs 
друштвеном времену и налазе се пред различитим развојним и еманципаторским задацима. Савремени Балкан, а посебно простор бивше Југославије, у знаку је постконфликтне трауматичне ситуације [...] У овом контексту у процесу транзиције балканских друштава модел просветитељства овде је замењен моделом тржишног фундаментализма, који је отворио процес разарања друштва, демонтаже социјалне државе и довео до културне и социјалне аномије“ (Митровић, 2009: 24-25). Постсоцијалистичке земље на Балкану суочавају се са бројним изазовима и проблемима у многим областима друштвеног живота. На простору бивше СФРЈ, у новонасталим државама, у последњој деценији 20. века ескалирали су верски и етнички сукоби и грађански рат, тако да се ове земље налазе не само у постсоцијалистичкој транзицији, већ и постконфликтном стању (Марковић Крстић и Милошевић Радуловић 2016: 116). Социодемографска анализа неких балканских земаља указује на неповољна демографска кретања, која су се јавила у другој половини 20. века, тако да се може очекивати њихово још снажније манифестовање током 21. века, уколико се не усмеравају адекватним мерама пронаталитетне популационе и социјане политике. „Данас постаје, међутим, све очигледније да се социјалне и популационе политике морају стално прилагођавати промењеној европској демографској ситуацији, пре свега израженом старењу, као последици недовољног рађања, али и продуженог живљења““ (Bobić, 2013: 154). Истраживачи социодемографских појава налазе се у положају посматрача-учесника својеврсног „природног експеримента“, чије ће последице (демографске) бити јасније изражене тек за неколико деценија.

У раду су, најпре, представљена теоријска полазишта за разумевање кретања становништва (теорија демографске транзиције, микроекономска теорија фертилитета), а потом је дат демографски приказ и анализа кретања становништва неких балканских земаља (демографска слика, природно кретање и старосна структура становништва). У фокусу рада су демографске промене, кретање и структуре становништва неких земаља Балкана сагледаних у контексту савремених друштвених трансформацијских процеса. У њему се трага за одговорима на питања о особеностима демографских структура балканских земаља, детерминантама формирања одређеног типа демографских структура у појединим балканским земљама, специфичним демографским карактеристикама балканских земаља и могућностима стварања „балканског“ демографског модела, повезаности демографских трендова у балканским земљама и политичких и друштвено-економских промена, као и о исходу одређених тенденција у кретању и структурама становништва, односно о демографској будућности ових земаља.

\section{ТЕОРИЈСКИ ПРИСТУПИ У ПРОУЧАВАҢУ ПРОМЕНА У КРЕТАҢУ СТАНОВНИШТВА}

Демографски процеси добијају специфична обележја у појединим земљама Балкана с обзиром на њихов географски положај, социо- 
економске, културне и етничке структуре. Етничке групе разликују се по културним стандардима, верској припадности, економској активности и диференцијалном фертилитету који доводи до брзих промена у демографским структурама становништва. У социјалној демографији је општеприхваћено становиште према коме друштвена структура и друштвене промене утичу на демографске структуре и процесе, на начин живота појединца, али и на његово репродуктивно понашање. С обзиром на то да је демографски развитак реверзибилан историјски процес, целина односа који се успостављају у становништву, веома је значајно проучавање утицаја друштвених чинилаца на демографске промене, као и утицај демографских кретања и структура на друштвене процесе. С једне стране, људска плодност и смртност, њихов однос у виду популациног раста, нису детерминисани искључиво биолошким факторима, већ су и социолошки, економски и шире културни феномени управо због своје опште друштвене, а потом и уже, стратификацијске условљености. С друге стране, различити друштвени слојеви, класе и друштвене групе, имају неједнаке шансе у погледу дужине живота, склапања брака, разликују се по броју деце и улагању у њихово образовање и социјалну промоцију (Bobić, 2007: 32). Теоријске интерпретације демографских промена су многобројне и разноврсне, а с обзиром на то да ће овде бити речи о променама у сфери брачног и репродуктивног понашања, као и паду наталитета, њихову окосницу ће чинити теорија демографске транзиције и економска теорија фертилитета.

Теорија демографске транзиције једна је од доминантних теорија која развитак становништва приказује као процес етапног развоја који се одвија у уској повезаности са етапама друштвено-економског развоја. Она је „широко прихваћена теоријска генерализација коју је 1929. године формулисао Ворен Томсон, а касније је разрадио Френк В. Нотештајн. Додуше, француски демограф Адолф Лондри је још 1909. године формулисао теорију троетапног демографског развитка, али јој је дао радикалнији назив 'теорија демографске револуције'“ (Bobić, 2007: 127). Промене које се дешавају (индустријализација и урбанизација) повезују се са променама у репродуктивном понашању становништва. Демографска транзиција, као заједничко демографско искуство развијених земаља света, своди се на преображај високог морталитета и фертилитета у ниски морталитет и фертилитет, на редукцију морталитета и фертилитета у последњих 200 година (Ђурђев, 1998: 60).

Ова теорија се темељи на основним поставкама: да је демографска транзиција историјски процес под непосредним утицајем фактора економског и друштвеног развоја и да садржи промене у наталитету (фертилитету), морталитету и природном прираштају, као и промене у демографским и економско-социјалним структурама становништва. Наиме, као што је целокупан демографски развој део ширих друштвено-економских промена у којима нема пасивну улогу пратиоца, већ и сам повратно утиче на друштвено-економске процесе, тако су и поједине етапе развоја становништва везане за историјски контекст 
друштвено-економских промена. Анализом историјских етапа развоја становништва и осветљавањем њиховог демографског садржаја настоје се уочити, генерализовати, кретања становништва својствена одређеним специфичним животним условима земаља које су у развоју становништва прошле кроз те етапе (Wertheimer-Baletić, 1999: 105).

Доналд Бог (Donald Bogue) развија троетапни модел демографске транзиције. Прва, предтранзиона етапа одликује се високим стопама наталитета и морталитета које резултирају веома ниским или чак нултим стопама природног прираштаја становништва. Другу етапу, етапу демографске транзиције (демографског прелаза) чине три подетапе. Прва подетапа транзиције одликује се високим стопама наталитета, док су стопе морталитета у јаком паду; долази до пораста становништва, старосна структура је изразито млада, становништво је концентрисано у пољопривредним занимањима и примарним делатностима уз преовладавајући удео сеоског живља. У другој подетапи започиње пад наталитета који је у односу на смањивање стопа морталитета нешто бржи, па стопа природног прираштаја започиње лагано падати; морталитет опада, али знатно спорије услед растућег учешћа старијих лица. У трећој подетапи стопа морталитета углавном стагнира на ниском нивоу, а стопа наталитета лагано пада па долази до смањивања стопа природног прираштаја. У старосној структури запажа се пораст старијих лица, становништво се све више концентрише у високопроизводним непољопривредним занимањима и у градовима. Највећи број популација развијених земаља данас припада овом типу становништва. Трећа, посттранзициона етапа одликује се ниским стопама наталитета и морталитета, које су веома блиске, тако да природни прираштај стагнира, док у појединим годинама може бити чак и негативан (Petrović, 1979: 5-7; Golubović i Marković Krstić, 2008: 13-14).

Демографска транзиција има различита обележја у појединим земљама у зависности од достигнутог друштвеног развоја. Тренд (етапни положај) недовољно развијених земаља у демографској транзицији знатно се разликује од етапног положаја који у демографској транзицији имају развијене земље 2 . Демографска транзиција је сложен процес који укључује како промене у природном кретању становништва и старосно-полној структури, тако и промене економских и социјалних структура становништва које су релевантне за демографски развитак. Према поставкама теорије демографске транзиције, етапе демографског развитка односе се на нормални развитак становништва (апстрахују се миграције, ратови) и могу бити аналитички оквир за проучавање развитка становништва.

Према поставкама теорије демографске транзиције, повезаност социоекономског развоја и репродукције становништва има исходиште у планирању породице, тако да се очекивало да ће се репро-

2 У највећем броју случајева недовољно развијене земље налазе се у етапном положају „демографске револуције“, у фази још увек високе стопе плодности и силазној стопи смртности. Последица тога је висок прираштај и нагли раст становништва, који једва стиже да прати спорији пораст средстава за људску егзистенцију. 
дукција становништва стабилизовати, а да ће резултат транзиционог процеса бити уравнотежена репродукција. Очекивања да ће се репродукција после етапе демографске транзиције стабилизовати на нивоу просте репродукције, односно да ће се наталитет и морталитет изједначити, нису се остварила. Осим тога, опадање фертилитета испољено је у различитим друштвеним, економским и демографским условима, планирање породице није било практиковано међу ширим слојевима сеоског становништва Европе, а културни фактори условили су почетак и интензивирање процеса опадања фертилитета независно од социоекономских услова. То је покренуло бројна преиспитивања поставки теорије демографске транзиције, односно покушаје да се уз помоћ нових емпиријских података објасне промене у репродуктивном понашању становништва. Социоекономски оквир објашњења репродукције и њених промена све више се замењује социокултурним у коме се траже објашњења најновијих промена (Handwrker, 1986). Уместо у социоекономском статусу појединца и породице објашњење се све више тражи у постиндустријском друштву у промењеним нормама и очекивањима појединца. Неки аутори наводе да су прве демографске промене регистроване у земљама Западне Европе, код становништва са вишим нивоом образовања, код оних који су усвојили постматеријалистичке вредности, повезане са индивидулизацијом и равноправношћу полова, код особа нижег степена религиозности и особа које мање подржавају ауторитете (Lesthaehge, Neidert, Surkyn, 2006; Petrović, 2011: 54).

Промене у репродукцији објашњавају се променама у структури породице и односу према репродукцији (Van de Kaa, 1987). Објашњење се налази у економској самосталности појединца и породице, могућностима планирања породице и односу према деци. Непосредно после Другог светског рата настојање да се заснује породица, да се имају деца, било је превасходно условљено социоекономским чиниоцима и жељом да се оствари економска самосталност. Са мењањем економских прилика, ширењем контрацептивних средстава, мењају се ставови према браку, предбрачним односима, броју деце у породици. Читав комплекс елемената који чине основу ставова о репродукцији се мења, па уместо притиска на младе да путем брака и породице остваре своју самосталност, они и без брака остварују економску самосталност и жељу за децом. Тиме социоекономски чиниоци не губе на важности, већ су достигли такав ниво да је квантитет порастао у квалитет. Дакле, економска самосталност младих људи омогућава им да се одвоје од родитеља, да живе у фактичкој заједници без склапања брака или да имају децу без склапања брака и сл. Ови и други елементи су оквир који утиче на промењени однос према репродукцији у већини развијених земаља. Аутор сматра да је дошло до транзиције од ,златног доба брака ка зори кохабитације“, од „ере краља-детета са родитељима ка ери пара-краља са дететом“, транзиције од „превентивне контрацепције ка самопотврђујућој концепцији“ 
и од ,униформне ка плуралистичкој породици и домаћинству“ (Van de Kaa, 1987: 11). Дакле, репродукција становништва је све мање под утицајем спољних чинилаца, а све више постаје слободна одлука појединца или пара (у већини земаља западне Европе).

Савремено економско објашњење фертилитета заступа амерички професор Гери Бекер (Gary Becker). Микроекономска теорија заснива се на принципима рационалности и максимизацији корисности. По принципу рационалности појединац бира оно што је за њега добро, а не лоше (бира задовољство, а не бол). Максимализација корисности значи да појединац рангира алтернативе и тражи ону која му доноси највећу корисност, а може потицати од материјалних добара, задовољства од сопствене великодушности, уживања у уметности или од подизања деце. Појединци имају различите преференције, односно приписују различиту корисност деци, материјалним добрима и осталим задовољствима, тако да веће преференције партнера у корист деце, повећавају њихову тражњу за децом (Mijatović, 2000: 59-74).

Г. Бекер је развио савремену економску теорију фертилитета (почевши од 1960. године), по којој се дете, у аналитичком смислу, сматра трајним потрошним добром. У том смислу, родитељи доносе одлуку о рађању детета, при чему воде рачуна о корисности коју ће имати од детета, а с друге стране, о висини трошкова, уз ограничења која им постављају доходак и цене. Дакле, дете доноси задовољство, али зато и троши ограничене ресурсе. Према поставкама ове теорије, фертилитет се разматра уз помоћ истих варијабли као и потрошња било које робе. С тим што постоје и разлике: деца се не изнајмљују на ограничено време, не мењају се за новији модел, нити се могу продати у време кризе, а осим тога, деца се не купују на тржишту. Г. Бекер је наглашавао разликовање квалитета деце и броја деце. Према његовом схватању, већи доходак, који остварују родитељи, утиче на њихов однос према деци, тако да већу пажњу придају квалитету деце. Такав однос према деци претпоставља издвајање већих средстава за свако дете, почевши од оних за исхрану и становање, образовање и здравље, до трошкова за путовања и спорт. Родитељи настоје да детету повећају шансе за квалитетан живот и успех у њему. На тај начин се ствара „људски капитал““ (human capital), који је, по савременој економској теорији, основни чинилац економског развоја. У том смислу, потенцијални родитељи врше избор између већег броја деце нижег квалитета и мањег броја деце вишег квалитета, у условима константног дохотка кога остварујуㄹ. Фертилитет се делом смањује током

3 „Повећање квалитета је скупље уколико је више деце, јер се повећање односи на већи број јединица; слично, повећање квантитета је скупље уколико су деца вишег квалитета, зато што деца вишег квалитета коштају више (Bесker, Lewis, 1973)“; Наведено према: Mijatović, 2000: 64. 
економског развоја услед повећања инвестиција у људски капитал деце, нарочито кроз образовање, тако да родитељи више улажу у децу, смањујући њихов број.

Разумевање промена и тенденција у кретању фертилитета уз помоћ основних поставки микроекономске теорије заснива се на теоријско-методолошком ставу да је рађање одлука појединаца на основу максимизације корисности, као и на укључивању економских детерминанти које утичу на рађање. Такав теоријски приступ, који полази од индивидуалног, рационалног и корисног, може бити пихватљив уколико се не заустави на разматрању само економских мотива рађања.

\section{ДЕМОГРАФСКА СЛИКА И СТАРОСНА СТРУКТУРА СТАНОВНИШТВА НЕКИХ БАЛКАНСКИХ ЗЕМАЉА}

Промене у друштвено-економској сфери утицале су на репродуктивно понашање становништва балканских земаља које се одликује константним опадањем фертилитета и измењеним односом према репродукцији. За разлику од ранијих периода, када су све за репродукцију способне жене рађале „онолико колико је бог дао“, данас је репродукција у неким земљама сведена на најмању меру, тако да не обезбеђује ни замену генерација. Поред тога, наглашене разлике у висини фертилитета у зависности од нивоа образовања, економске активности, националне и религијске припадности сведоче о постепеном одбацивању традиционалног модела рађања и превладавању савременог, који подразумева рађање једног детета или двоје деце (недостатак мотива и жеље за рађањем деце, одбацивање могућности да се учествује у репродукцији). Снижавање фертилитета иде у корак са променама, како у старосно-полној и брачној структури ,у правцу смањења удела лица која су у браку, повећања старости приликом ступања у брак, пораста учешћа лица која нису склапала брак и пораста броја разведених лица" (Pešić Jenaćković, 2018: 73), тако и у социоекономским и културноантрополошким структурама становништва. Промењене друштвене прилике стварају мотивацију за ограничавање рађања, промењена је улога жене у породици и друштву, као и значај деце за родитеље и друштво.

Резултат таквог репродуктивног понашања и односа према репродукцији је константно опадање вредности стопа природног прираштаја, које у већини балканских земаља имају негативни предзнак. Међутим, интензитет промена није у свим земљама Балкана исти, далеко је већи у нисконаталитетној Босни и Херцеговини, Грчкој, Хрватској, Бугарској, Србији у односу на Албанију, Црну Гору и Северну Македонију. Ово делом показује да савремени модернизацијски токови, као главни покретачи промена, како у друштвеним и економским сферама, тако и демографској, још увек нису доминантно прихваћени међу становништвом појединих земаља Балкана, тако да традиционални систем вредности, етничка и верска припадност, као и начин живота битно утичу на формирање репродуктивних норми и остварени ниво фертилитета. 
Табела 1: Демографски показатељи у балканскии земъама, 1951. і 2016. година

\begin{tabular}{|c|c|c|c|c|c|c|c|c|c|c|c|c|}
\hline \multirow{2}{*}{\begin{tabular}{||c|} 
Земља \\
Година \\
\end{tabular}} & \multicolumn{2}{|c|}{$\begin{array}{l}\text { Број стан. у } \\
\text { милионима }\end{array}$} & \multicolumn{2}{|c|}{$\begin{array}{c}\text { Стопа } \\
\text { наталитета }\end{array}$} & \multicolumn{2}{|c|}{$\begin{array}{c}\text { Стопа } \\
\text { морталитета }\end{array}$} & \multicolumn{2}{|c|}{$\begin{array}{c}\text { Стопа пр. } \\
\text { прираштаја }\end{array}$} & \multicolumn{2}{|c|}{$\begin{array}{c}\text { Стопа } \\
\text { нупцијалит. }\end{array}$} & \multicolumn{2}{|c|}{$\begin{array}{c}\text { Стопа } \\
\text { диворцијал. }\end{array}$} \\
\hline & 1951 & 2016 & 1951 & 2016 & 1951 & 2016 & 1951 & 2016 & 1951 & 2016 & 1951 & 2016 \\
\hline Алббанија & 1,24 & 2,89 & 38,5 & 11,5 & 15,2 & 7,8 & 23,3 & 3,7 & 10,2 & 8,7 & 0,9 & $1, \overline{1,3}$ \\
\hline Би $\mathrm{X}$ & 2,72 & 3,51 & 33,9 & 8,3 & 17,0 & 10,1 & 16,9 & $-1,8$ & 11,3 & $4,8^{4}$ & 0,7 & 0,6 \\
\hline Bугарска & 7,26 & 7,15 & 21,1 & 9,1 & 10,7 & 15,0 & 10,4 & $-5,9$ & 8,9 & 3,9 & 0,8 & 1,5 \\
\hline Грчка & 7,65 & 10,78 & 20,3 & 8,6 & 7,5 & 11,0 & 12,8 & $-2,4$ & 8,3 & 5,0 & 7 & $1,3^{5}$ \\
\hline Румунија & 16,46 & 19,76 & 25,1 & 9,5 & 12,8 & 13,0 & 12,3 & $-3,5$ & 10,3 & 6,3 & 1,2 & 1,6 \\
\hline $\begin{array}{l}\text { C. } \\
\text { Makenoнija }\end{array}$ & 1,26 & 2,07 & 35,9 & 11,1 & 16,4 & 9,9 & 19,5 & 1,2 & 10,8 & 6,8 & 0,8 & 1,0 \\
\hline Словенија & 1,49 & 2,06 & 22,8 & 9,9 & 12,4 & 9,5 & 10,4 & 0,4 & 8,9 & 3,1 & 0,6 & 1,2 \\
\hline Србија & 6,82 & 7,06 & 25,6 & 9,2 & 13,9 & 14,3 & 11,7 & $-5,1$ & 10,8 & 5,1 & 1,2 & 1,3 \\
\hline Хрватска & 3,88 & 4,19 & 22,5 & 9,0 & 12,8 & 12,3 & 9,6 & $-3,3$ & 9,0 & 4,7 & 0,8 & 1,4 \\
\hline $\begin{array}{l}\text { Црна } \\
\text { Гора }\end{array}$ & 0,41 & 0,62 & 31,7 & 12,2 & 10,9 & 10,4 & 20,8 & 1,8 & 8,1 & 5,1 & 0,5 & 1,1 \\
\hline
\end{tabular}

Извор: Kotzamanis, 2001: 7-44; P3C, 2017: 60-62; P3C, 2017a: 48; P3C, 2018: 37; World factbook 2018; EUROSTAT 2018; MONSTAT, 2018: 38-42. Worldometers.info/world-population

Друштвена, културна, конфесионална разноликост на овим просторима одразила се и на демографска кретања у периоду 19512016. (Табела 1) тако да се диференцирају две групе земаља с обзиром на демографске карактеристике и тенденције у кретању становништва: на једној страни су Албанија (3,7\%), Црна Гора $(1,8 \%)$, Северна Македонија $(1,2 \%)$ и Словенија $(0,4 \%)$ са позитивним природним прираштајем, а на другој су остале (овде приказане) земље Балкана у којима је природни прираштај негативан (у Бугарској $-5,9 \%$; Србији $-5,1 \%$, Румунији $-3,5$, Хрватској $-3,3 \%$; Грчкој $-2,4 \%$ и Босни и Херцеговини $-1,8 \%$ ). Стопе нупцијалитета смањују се у свим земљама Балкана (у периоду 1951-2016), тако да су у неким вредности преполовљене (Босни и Херцеговини, Бугарској, Хрватској и Србији), док је у Словенији смањење још веће (за 2/3). Кретање стопа диворцијалитета је такође једносмерно, али у обрнутом правцу у односу на стопе нупцијалитета - у скоро у свим земљама показују тенденцију повећања (највеће повећање, односно дуплирање вредности стопа диворцијалитета забележено је у Црној Гори са $0,5 \%$ на $1,1 \%$ и Словенији $0,6 \%$ на $1,2 \%$ ), док је само у Босни и Херцеговини дошло до незнатног смањења (за $0,1 \%$ ).

Актуелни трендови у кретању нупцијалитета и диворцијалитета резултирају и промењеним односом према родитељству. „Кретање нупцијалитета у последњих петнаестак година показује јасан силазни тренд у безмало свим европским земљама... Стопа укупне брачности почела је да опада прво у скандинавским земљама, посебно у Шведској и Данској половином 1960-их, а потом су следиле сличне промене у већини европских земаља почетком 1970-их. Извесне промене у том правцу догађају се и у Југославији у 1980-им и могле би да значе почетак краја ере када су се ,сви“ венчавали“ (Avramov, 1993: 107-108). Опадање стопе укупне брачности на нашим просторима је једним делом последица одлагања брака услед неповољних економских прилика, али и знак да је дошло до смањења привлачности законом регули-

4 Подаци за стопе нупцијалитета и диворцијалитета у Б и Х односе се на 2012. годину.

5 Подаци за стопу диворцијалитета односе се на 2012. годину. 
сане заједнице жене и мушкарца. „Код млађе популације однос према браку се огледа у константном паду броја закључених бракова, којих je 2010. било за око трећину мање него 1980. године. Стопа склопљених бракова на 1000 становника је пала са 5,1 на 4,9 од 2009. до 2010. Један део осипања свакако се може приписати кохабитацији, али је вероватније да је већи део везан за саму промену понашања према заједничком животу у браку, као и за процес старења популације, што доводи до смањивања брачног контингента“ (Благојевић Хјусон, 2012: 36). М. Благојевић Хјусон такође наводи да се промена односа према браку огледа и у порасту старости супружника приликом склапања првог брака, која је 2010. године била 30,8 година за мушкарце и 27,1 година за жене. Померање ове границе доводи до померања границе рађања, тако да је просечна старост мајке при рођењу првог детета износила 27,2 године (2010), што потврђује да је процес модернизације брака и брачности у току.

Последице оваквог тренда кретања стопа нупцијалитета и честог одлагања ступања у брак, свакако остављају трага на породицу као заједницу. Она све више губи неке од својих функција. Једна од оних која се видно трансформише јесте репродуктивна функција, која се описује и мери прецизним показатељем: бројем рођене деце. Бројни аутори указују на то да је дошло до велике „кризе“ породице, да се у брак ступа све касније, да је све више краткотрајних и дуготрајних ванбрачних заједница које су, по правилу, без деце, а промењени су и ставови према рађању (неке поборнице екстремног феминизма тврде да је и само рађање један облик експлоатације жене).

Анализа демографских кретања балканских земаља показује да је процес демографске транзиције завршен или је при крају и да је у складу са темпом друштвеног и економског преображаја. Иако су на подручју Балкана били присутни различити модели репродукције (традиционални и савремени) током 20. века, а балканске земље се суочавале са популационим проблемима, недовољним или прекомерним рађањима појединих етничких група које су се разликовале по културним стандардима, верској припадности, економској активности, диференцијалном фертилитету (што је доводило до брзих промена у етничком саставу становништва и повећању социјалних тензија), у другој деценији 21. века долази до релативног „уједначавања“ демографских показатеља. Кретање становништва Балкана условљено је природним прираштајем, али и миграционом компонентом која има посебан значај у територијалној редистрибуцији становништва и етничкој структури у етнички хетерогеним срединама.

Статистички подаци о природном кретању становништва у земљама Балкана показују да су неке од њих већ ушле у раздобље посттранзиције или се налазе на његовом почетку, јер облик репродукције у коме долази до опадања наталитета тако да је приближно једнак нивоу морталитета одговара посттранзицијском режиму репродукције.

Како је рађање кључна демографска варијабла и позитивна компонента природног прираштаја, у условима ниске смртности становништва, основни је динамички чинилац демографских промена. У 
том смислу, праћење промена у стопама укупног фертилитета послужиће бољем разумевању данашње демографске структуре балканских земаља (Табела 2).

Табела 2: Стопа укупнов фертилитета у балканскии земьама (1970-2019)

\begin{tabular}{||l|c|c|c|c|c|c|c||}
\hline \hline \multicolumn{1}{|c|}{ Земља } & $\mathbf{1 9 7 0 .}$ & $\mathbf{1 9 8 0 .}$ & $\mathbf{1 9 9 0 .}$ & $\mathbf{1 9 9 9 .}$ & $\mathbf{2 0 0 3 .}$ & $\mathbf{2 0 1 7 .}$ & $\mathbf{2 0 1 9 .}$ \\
\hline Албанија & 5,2 & 3,6 & 3,0 & 2,3 & 2,2 & 1,5 & 1,6 \\
\hline Босна и Херцеговина & 2,7 & 1,9 & 1,7 & $/$ & 1,7 & 1,3 & 1,3 \\
\hline Бугарска & 2,2 & 2,1 & 1,8 & 1,2 & 1,1 & 1,5 & 1,6 \\
\hline Грчка & 2,4 & 2,2 & 1,4 & 1,3 & 1,3 & 1,4 & 1,3 \\
\hline Румуннја & 2,9 & 2,5 & 1,8 & 1,3 & 1,4 & 1,4 & 1,6 \\
\hline Северна Македонија & 3,0 & 2,5 & 2,1 & 1,8 & 1,8 & 1,6 & 1,5 \\
\hline Словенија & 2,1 & 2,1 & 1,5 & 1,2 & 1,3 & 1,4 & 1,6 \\
\hline СФРЈ, СРЈ , СЦГ & 2,3 & 2,3 & 2,1 & $/$ & 1,7 & $/$ & $/$ \\
\hline Србија & 2,4 & 2,4 & 2,2 & 1,8 & 1,6 & 1,5 & 1,5 \\
\hline Хрватска & $/$ & 1,9 & 1,6 & 1,4 & 1,9 & 1,4 & 1,4 \\
\hline Црна Гора & 2,6 & $2,3 *$ & 1,9 & 1,8 & 1,8 & 1,8 & 1,8 \\
\hline \hline
\end{tabular}

Извор: Breznik, 1991: 52; Balkan Demographic Data Base; EUROSTAT 2000; World factbook, 2004 и 2018; MONSTAT, 2018: 43; http://data.un.org; P3C, 2011: 64-66; Р3C, 2018: 51. http://www.worldometers.info, EUROSTAT 2020.

Репродукција становништва балканских земаља и разлике у фертилитету последице су дугорочног дејства многобројних чинилаца, структуралних карактеристика и вредносних система. Опадање стопа укупног фертилитета присутно је у свим балканским земљама током периода 1970-2019. године, мада са значајним разликама у интензитету смањења. Док су у појединим земљама стопе укупног фертилитета преполовљене: у Босни и Херцеговини (2,7\%о на 1,3\%o), Северној Македонији (3,0\%о на $1,5 \%$ ) и Румунији (2,9\%о на $1,6 \%$ ), у неким од њих дошло је до већег смањења високих стопа укупног фертилитета: у Албанији (ca 5,2\% у 1970. на 1,6\% у 2019. години) или мањег смањења: у Бугарској (2,2\%о у 1970. на 1,6\% у 2019. години), Словенији $(2,1 \%$ на $1,6 \%)$, Црној Гори $(2,6 \%$ он $1,8 \%$ ), Србији $(2,4 \%$ на $1,5 \%$ ) и Грчкој $(2,4 \%$ на $1,3 \%$ ). С обзиром на то да је у свим земљама стопа укупног фертилитета испод вредности која обезбеђује генерацијско обнављање становништва $(2,14)$ могу се очекивати бројни демографски проблеми изражени у виду депопулације и старења становништва у већини балканских земаља.

Смањење фертилитета може се објаснити дејством многобројних чинилаца, од оних економске природе (лоши материјални услови, економска несигурност и зависност, стамбене прилике), преко чинилаца који се односе на здравствено стање, старост партнера и брачно стање, до оних који су у вези са стресним стањима и присутном неизвесношћу услед етничких сукоба у појединим земљама, а који делују у правцу смањења броја деце или чак одустајања од рађања. Велике промене у обиму

\footnotetext{
* Подаци за 1970. годину, 1980. годину и 1990. годину - СФРЈ, за 1999. годину СРЈ, а за 2003. годину - СЦГ.

** Подаци за Црну Гору односе се на 1976. годину (Breznik, 1991: 52).
} 
рађања последњих деценија иду укорак са променама у економској, социјалној и образовној структури друштва. Поред тога, непостојање адекватне популационе политике и одсуство јасне поруке друштва о потреби и значају биолошке репродукције становништва, као и непознавање катастрофалних поселедица постојећих трендова рађања, доприносе даљем настављању тенденције опадања становништва у поједним земљама.

Објашњење темпа промена у сфери природног кретања становништва не може се посматрати одвојено од старосне структуре. Формирана старосна структура, односно достигнута демографска старост становништва снажно утиче на ниво и смер промена природних компоненти кретања становништва. У Табели 3 приказан је распоред становништва по великим старосним групама у појединим земљама Балкана.

Табела 3: Старосна структура становниитва балканских зеиаља по великии староснии әрупама (1951, 1998. и 2017. година) у \% и просечна старост 2017.

\begin{tabular}{|c|c|c|c|c|c|c|c|c|c|c|}
\hline \multirow[b]{2}{*}{ Земља } & \multicolumn{3}{|c|}{1951.} & \multicolumn{3}{|c|}{1998.} & \multicolumn{3}{|c|}{ 2017. } & \multirow{2}{*}{$\begin{array}{c}2017 . \\
\text { Просечна } \\
\text { старост/год. }\end{array}$} \\
\hline & $0-14$ & $15-64$ & $65+$ & $0-14$ & $15-64$ & $65+$ & $0-14$ & $15-64$ & $65+$ & \\
\hline Албанија & 38,7 & 54,3 & 7,0 & 32,6 & 61,3 & 6,1 & 18,1 & 70,1 & 11,9 & 32,9 \\
\hline Босна и Херцеговина & 39,2 & 57,7 & 3,1 & 18,8 & 71,2 & 9,9 & 13,3 & 72,3 & 14,4 & 42,1 \\
\hline Бугарска & 26,7 & 64,9 & 8,4 & 16,5 & 67,7 & 15,7 & 14,6 & 66,1 & 19,3 & 42,7 \\
\hline Грчка & 28,2 & 64,9 & 6,9 & 15,6 & 67,7 & 16,7 & 13,8 & 65,3 & 20,9 & 44,5 \\
\hline Румунија & I & I & 1 & 19,1 & 68,0 & 12,8 & 14,4 & 69,2 & 16,4 & 41,1 \\
\hline Северна Македонија & 37,0 & 57,5 & 5,6 & 23,3 & 67,3 & 9,4 & 17,2 & 69,4 & 13,4 & 37,9 \\
\hline Словенија & 27,5 & 65,2 & 7,3 & 16,8 & 69,8 & 13,4 & 13,3 & 67,2 & 19,5 & 44,5 \\
\hline CФPJ, CPJ & 30,9 & 63,5 & 5,7 & 21,1 & 66,4 & 12,4 & 1 & i & 1 & I \\
\hline $\mathrm{Cp}_{\text {рнган }}{ }^{* *}$ & 27,5 & 66,0 & 6,5 & 16,0 & 66,5 & 17,5 & 14,4 & 66,0 & 19,6 & 43,0 \\
\hline Хрватска & 27,3 & 66,1 & 6,7 & 19,9 & 67,8 & 12,3 & 14,2 & 66,5 & 19,3 & 43,0 \\
\hline Црна Гора & 35,5 & 57,1 & 7,4 & 20,6 & 67,4 & 12,0 & 18,3 & 67,5 & 14,2 & $37,2^{+4 *}$ \\
\hline
\end{tabular}

Извор: Balkan Demographic Data Base; World factbook, 2018; MONSTAT, 2017: 2; MONSTAT, 2017a: 8; P3C, 2018: 37-38.

Распоред становништва балканских земаља по старосним групама током периода 1951-2017. године указује на тенденцију интензивног смањења процентуалног учешћа младог становништва (старосна група 0-14 године) и повећања броја становника који припадају старосним групама 15-64 године и 65 и више година. Постоје значајне разлике у процентуалном уделу појединих старосних група у земљама Балкана - док је најмлађе становништво 1951. године чинило скоро трећину или нешто више од трећине укупног становништва балканских земаља, 2017. године оно чини нешто више од шестине укупног становништва у овим земљама. Међутим, издвајају се земље у којима има највише младог становништва до 14 година у односу на друге земље (Црна Гора - 18,3\%, Албанија - 18,1\% и Северна Македонија - 17,2\%) и старог становништва - 65 и више година (Грчка $-20,9$, Србија - 19,6\%, Словенија - 19,5, Бугарска - 19,3 и Хрватска - 19,3).

\footnotetext{
* Подаци за Црну Гору дати су за 2016. годину; MONSTAT, 2017: 2.

** Подаци за Србију односе се на 1953, 2002 і 2017. годину.

*** Подаци се односе на 2011. годину; MONSTAT, 2017a: 8.
} 
С обзиром на дистрибуцију становништва по старосним групама и веће присуство старог у односу на младо становништво у појединим земљама (у Грчкој, Србији, Словенији, Бугарској, Хрватској), може се предвидети повећање морталитета, старење становништва и незавидна демографска будућност ових земаља. Демографске пројекције (на примеру Хрватске) указују на то да ће се становништво кретати према ниској варијанти наталитета, што проистиче: а) из досадашњих дугорочних демографских трендова стопа природног кретања, б) из старосне структуре становништва, ц) из обележја становништва у посттранзицијској етапи (у којој се налази становништво Хрватске), д) из деловања демографске инерције (,демографског моментума“), коју обележавају предвиђене промене старосне структуре становништва с обзиром на прошла кретања виталних стопа (Nejamšić, 2005: 68).

Да се ради о незавидној демографској будућности потврђују и стадијуми демографске старости појединих земаља. Наиме, док се Албанија (32,9 г.) налази на прагу демографске старости (четврти стадијум; 30-35 година), а Црна Гора $(37,2$ г.) и Северна Македонија $(37,9$ г.) у петом стадијуму демографске старости (35-40 година), остале земље се налазе у шестом стадијуму дубоке демографске старости (40-43 године): Румунија (41,1 г.), Босна и Херцеговина (42,1 г.), Бугарска (42,7 г.), Србија $(43,0$ г.) и Хрватска (43 г.). У последњем, седмом стадијуму најдубље демографске старости (43+) налазе се: Грчка $(44,5$ г.) и Словенија $(44,5$ г.).

Балканске земље су почетком 21. века суочене са великим демографским проблемима: смањењем удела младог и повећањем удела старог становништва у укупној популацији, смањеном репродукцијом и њеном најтежом последицом - процесом интензивног старења становништва. Присутне разлике у кретању становништва међу појединим земљама у складу су са њиховим географским, економским, етничким, религијским и културним обележјима. С обзиром на то да су демографски процеси базични друштвени процеси, а демографски показатељи синтетички друштвени показатељи (тј. друштвени и демографски процеси међусобно су повезани), неопходно је предузимање одговарајућих мера у вези са негативним популационим кретањима, које могу бити успешне само уколико су међусобно интегрисане са мерама за решавање социоекономских проблема, како младих, тако и старијих људи у земљама Балкана.

\section{ЗАКЉУЧАК}

У циљу теоријског и емпиријског проучавања демографских процеса и промена у сфери природног кретања становништва неких балканских земаља, у раду се пошло од кључних поставки теорије демографске транзиције, а потом су представљени и интерпретирани резултати истраживања демографских промена ових земаља у контексту савремених друштвених и трансформацијских процеса на Балкану.

Анализа кретања становништва балканских земаља показује да је код једне групе земаља процес демографске транзиције завршен или је при крају, док је код друге групе у току, у складу са споријим темпом друштвеног и економског преображаја. Различити модели репродукције 
присутни су на подручју Балкана, тако да се балканске земље суочавају са популационим проблемима у виду недовољног рађања и немогућности генерацијског обнављања, што доприноси депопулацији и демографском старењу већег броја балканских земаља. Етничке групе се разликују по културним стандардима, верској припадности, економској активности, диференцијалном фертилитету који доводи до брзих промена у етничком саставу становништва, а разлике у моделу репродукције у вишенационалним заједницама могу утицати на повећање социјалних тензија.

Анализа природног кретања становништва у балканским земљама током друге половине 20. века и у првим деценијама 21. века указују на хетерогеност, односно постојање две групе земаља са различитим демографским тенденцијама и карактеристикама. Прву групу чине Албанија, Црна Гора и Северна Македонија, а другу остале земље на простору Балкана. Првој су својствене карактеристике: више стопе наталитета, позитиван природни прираштај и веће учешће младог становништва у укупној популацији у односу на остале земље (чије је кретање становништва проучавано). Одустајање од рађања није појава маргиналних димензија, већ значајан социодемографски феномен који током времена доводи до дугорочних негативних демографских трендова, у виду настављања и интензивирања процеса депопулације и старења становништва већине балканских земаља. Пошто интервенције на демографском плану у већини балканских земаља изостају или не дају задовољавајуће резултате, могу се очекивати директне негативне последице трендова компоненти популационе динамике и индиректне на структуре становништва.

\section{ЛИТЕРАТУРА}

Avramov, D. (1993) Pojedinac, porodica i stanovništvo u raskoraku. Beograd: Naučna knjiga.

Becker, G. S. \& H. G. Lewis (1973) „On the Interaction Between Quantity and Quality of Children“, Journal of Political Economy, 2, Part II, pp. 280.

Благојевић Хјусон, М. (2012) Жене и мушкарии у Србији: шта нам говоре бројеви? Београд: Програм Уједињених нација за развој.

Bobić, M. (2007) Demografija i sociologija - veza ili sinteza. Beograd: Službeni glasnik.

Bobić, M. (2013) Postmoderne populacione studije. Beograd: Institut za sociološka istraživanja Filozofskog fakulteta Univerziteta u Beogradu.

Breznik, D. (1991) Stanovništvo Jugoslavije. Titograd: „CHRONOS“.

Van de Kaa, D. J. (1987) Europe's Second Demographic Transition. Population Bulletin, Vol. 42, No. 1. pp. 1-59.

Wertheimer-Baletić, A. (1999) Stanovništvo i razvoj. Zagreb: Mate.

Golubović, P. i S. Marković Krstić (2008) Demografske strukture nekih balkanskih zemalja. Niš: Filozofski fakultet Univerziteta u Nišu.

Ђурђев, Б. (1998) Географија становништва. Нови Сад: Универзитет у Новом Саду и ПМФ. 
Handwerker, W. P. (1986) „Culture and Reproduction: Exploring MicroMakro Linkages“, Editied by Handwerker P.: Culture and reproduction - an Anthropological Critique of Demographic Transition Theory. A Westview Special Study, Westview Press - Boulder and London.

Kotzamanis, B. (2001) „Razvitak stanovništva i demografske perspektive jugoistočne Evrope“, Stanovništvo, XXXIX, 1-4, str. 7-44.

Lazić, M. i drugi (2000) Račji hod. Srbija u transformacijskim procesima. Beograd: „Filip Višnjićc“.

Lesthaeghe, R., L. Neidert, J. Surkiyn (2006) „Household Formation and the ,Second demographic transition" in Europe and the U.S. Insights from middle range models", http://sdt.psc.isr.umich.edu/pubs/online/rl_ romantic_unions_paper.pdf.

Марковић Крстић, С. и Л. Милошевић Радуловић (2016) Хуманистичка димензија образовања младих у контексту савремених друштвених промена. Ниш: Филозофски факултет Универзитета у Нишу.

Mijatović, B. (2000) „O mikroekonomskoj teoriji fertiliteta“. Stanovništvo. XXXVIII, 1-4, str. 59-78.

Митровић, Љ. (2009) „Геополитичка транзиција Балкана, евроинтеграцијски процеси и култура мира““. У: Међуетнички односи, идентитети и култура мира на Балкану. Пр. Митровић, Љ., Захаријевски Д. и Д. Гавриловић. Ниш: Филозофски факултет и Центар за социолошка истраживања, стр. 11-28.

MONSTAT (2017) Saopštenje, broj 98. Podgorica: Zavod za statistiku Crne Gore.

MONSTAT (2017a) Crna Gora u brojkama 2017. Podgorica: Zavod za statistiku Crne Gore.

MONSTAT (2018) Statistički godišnjak Crne Gore, Podgorica: Zavod za statistiku Crne Gore.

Nejamšić, I. (2005) Demografija: stanovništvo u prostornim odnosima $i$ procesima. Zagreb: Školska knjiga.

Pešić Jenaćković, D. (2018) „Vanbračne zajednice“, Sociološka luča, XII/1, str. 66-79.

Petrović, R. (1979) Demografija. Beograd: Arhitektonski fakultet.

Petrović, M. (2011) „Promene bračnosti i porodičnih modela u postsocijalističkim zemljama: zakasnela i nepotpuna ili specifična druga demografska tranzicija“, Stanovništvo, Vol. 49, br. 1/2011, str. 53-78.

РЗС (2011) Демографска статистика у Републици Србији. Београд: P3C PC.

РЗС (2017) Демографска статистика 2016. Београд: РЗС РС.

РЗС (2017а) Статистички годишњак. Београд: РЗС РС.

РЗС (2018) Статистички годишњак Републике Србије. Београд: РЗС PC.

http://data.un.org/Data.aspx?d=SOWC\&f=inID\%3A127 (pristup: april 2019). 
http://ec.europa.eu/eurostat/web/products-statistical-books/-/KS-CN-02001-3A (pristup: april 2019).

http://Europa.eu/eurostat/tgm/refreshTableAction.do?tab/ec.uuropa.eu/ eurostat/data/database (pristup: april 2019).

http://www.worldometers.info/world-population/montenegro-population/ (pristup: april 2019).

http://www.worldometers.info/world-population/serbia-population/ (pristup: mart 2019).

http://www.worldometers.info. EUROSTAT 2020. (pristup: februar 2020).

https://ec.europa.eu/eurostat/statistics-explained/images/0/09/Total_ fertility_rate\%2C_1960\%E2\%80\%932013_\%28live_births_per_woman. png (pristup: mart 2019).

https://unstats.un.org/unsd/demographic-social/products/dyb/ dybcensusdata.cshtml (pristup: april 2019).

https://www.cia.gov/library/publications/download/download-2004/index. html (pristup: decembar 2004).

https://www.cia.gov/library/publications/the-world-factbook/fields/2018. html (pristup: april 2018).

https://www.google.rs/search?q=Balkan+Demographic+Data+Base (pristup: decembar 2018).

\title{
DEMOGRAPHIC CHANGE IN SOME BALKAN COUNTRIES IN THE TRANSITION CONTEXT
}

\begin{abstract}
Summary
Demographic change is an integral part of the deeper socio-economic changes that the Balkan countries have undergone in the second half of the 20th and the beginning of the 21 st century. Numerous unfavorable demographic trends have continued or intensified, and some demographic processes (declining natural growth, aging populations, depopulation) have become more prominent in the Balkans, so their more powerful manifestation is expected during the 21 st century. Changes in the demographic picture of the Balkan countries and the differences in population reproduction are conditioned by the nature of the socioeconomic nature of the circumstances, the multiplicity of the factors of ethnicity, as well as the civilization and cultural characteristics of certain social groups. The changes in the natural movement sphere and the age structure of the population of some Balkan countries over the last several decades have been examined in this paper from the socio-demographic perspective. The study of the peculiarities of particular demographic structures, population movements, marital and reproductive behavior of the population indirectly points to the answer to the question of the demographic future of these countries.
\end{abstract}

Key words: demographic change, Balkan countries, natural population movements, depopulation, population aging. 